\title{
MEMBENTUK MAHASISWA WIRAUSAHA MELALUI PROGRAM PENGEMBANGAN KEWIRAUSAHAAN
}

\author{
Grace Jenny Soputan ${ }^{1}$,Nova Ch. Mamuaya ${ }^{2}$, Made Krisnanda ${ }^{3}$ \\ ${ }^{1}$ Jurusan Manajemen, Fakultas Ekonomi, Universitas Negeri Manado \\ ${ }^{2}$ Jurusan Manajemen, Fakultas Ekonomi, Universitas Negeri Manado \\ ${ }^{3}$ Jurusan Teknologi Informasi, Fakultas Teknik, Universitas Negeri Manado \\ 1' gracesoputan@unima.ac.id, ${ }^{2)}$ novachmamuaya@unima.ac.id ${ }^{3)}$ madekrisnanda@unima.ac.id
}

\begin{abstract}
Abstrak
Pengangguran terdidik masih menjadi masalah sampai saat ini di Indonesia. Tanggung jawab untuk mengatasi masalah tersebut adalah lembaga pendidikan termasuk Perguruan Tinggi. Permasalahan di Fakultas Ekonomi Universitas Negeri Manado hanya sebagian kecil mahasiswa yang melakukan kegiatan usaha atau merintis usaha. Fenomena yang terjadi para lulusan masih menganggur karena lapangan kerja yang tersedia terbatas. Program Pengembangan Kewirausahaan merupakan salah satu kegiatan Pengabdian kepada Masyarakat untuk membantu melahirkan wirausaha baru di lingkungan mahasiswa. Tujuan kegiatan ini untuk membekali dan melatih mahasiswa menjadi seorang wirausaha yang mandiri dengan merintis usaha baru. Jumlah mahasiswa yang mengikuti kegiatan ini dipilih 20 orang di Fakultas Ekonomi yang berasal dari Program Studi Manajemen, Akuntansi, Pendidikan Ekonomi, dan Ilmu Ekonomi. Metode kegiatan menggunakan pelatihan, praktikum, pendampingan, dan magang dan dilaksanakan selama 4 bulan. Pelatihan dan magang dilaksanakan di beberapa tempat UKM yang dipilih. Hasil yang dicapai terdapat 7 mahasiswa yang mulai merintis usaha baru antara lain, usaha makanan ringan, aneka minuman kekinian, kerajinan, dan multi fungsi. Motivasi berwirausaha dari mahasiswa harus diikuti dengan intervensi dari dosen sebagai pendamping.
\end{abstract}

Kata kunci: Wirausaha baru; Program Pengembangan Kewirausahaan; Mahasiswa

\section{PENDAHULUAN}

Minat lulusan perguruan tinggi sampai saat ini lebih tertarik menjadi Pegawai Negeri Sipil (PNS) atau Aparatur Sipil Negara (ASN) dibandingkan dengan lapangan pekerjaan yang lain apalagi menjadi seorang wirausaha. Mahasiswa masih memiliki persepsi bahwa menjadi wirausaha adalah pekerjaan sampingan. Pekerjaan utama yang diinginkan adalah menjadi pegawai negeri atau pegawai BUMN. Para lulusan merasa bangga jika mereka bekerja sebagai pegawai negeri sipil. Konsekwensi dari keinginan tersebut maka para mahasiswa dari tahun ke tahun masih kurang tertarik untuk mengikuti program kewirausahaan yang dilaksanakan pihak perguruan tinggi. Masalah yang terpantau di Universitas Negeri Manado dari tahun ke tahun jumlah mahasiswa yang menjadi wirausaha relatif sedikit, padahal setiap tahun Program Mahasiswa Wirausaha dilaksanakan. Tawaran program kewirausahaan baik dalam Program Kreativitas Mahasiswa maupun Program Mahasiswa Wirausaha belum dimanfaatkan oleh mahasiswa. Permasalahan yang terpantau bahwa mahasiswa belum berminat memanfaatkan peluang yang ada karena kemampuan untuk menyusun proposal masih rendah, tidak ada pendampingan atau bimbingan dari dosen. Fenomena lain yang terpantau, dalam perkuliahan kewirausahaan masih sebatas untuk mendapatkan nilai akhir dari mata kuliah tersebut. Selain itu mahasiswa belum berpikir untuk merintis usaha karena biaya perkuliahan dan lainnya masih menjadi tanggung jawab orang tua. Dengan demikian para mahasiswa tidak berpikir untuk merintis usaha guna mendapatkan penghasilan sendiri.

Kondisi di Fakultas Ekonomi Universitas Negeri Manado pada tahun 2020 jumlah mahasiswa yang lolos Program 
Mahasiswa Wirausaha untuk didanai hanya 18 mahasiswa. Hasil pemantauan bahwa dari 18 penerima pendanaan PMW usaha mereka tidak berkesinambungan. Penyebabnya kurangnya kompetensi kewirausahaan, kurang percaya diri dalam bersaing, pemahaman yang keliru tentang wirausaha yaitu berdagang (Soputan, dkk, 2021)

Melihat permasalahan di atas maka perlu intervensi terhadap mahasiswa untuk meningkatkan kompetensi kewirausahaan melalui Program Pengembangan Kewirausahaan. Tujuan kegiatan ini untuk memberikan pengetahuan dan ketrampilan kepada mahasiswa untuk menjadi seorang wirausaha. Selain itu memberikan motivasi dalam menghadapi tantangan ke depan untuk menciptakan lapangan kerja bukan sebagai pencari kerja.

\section{METODE}

Kegiatan Pengembangan Kewirausahaan dilaksanakan dengan menggunakan metode pelatihan/pembekalan, praktikum, dan pendampingan. Langkah-langkah kegiatan untuk mencapai tujuan ditempuh sebagai berikut: 1) Sosialisasi dan rekrutmen calon peserta. Sosialisasi dilakukan pada saat pemberian perkuliahan semester genap pada semua program studi yang ada di Fakultas Ekonomi. Rekrutmen dilaksanakan secara online melalui google form. Seleksi peserta mengacuh pada kriteria yang telah ditetapkan oleh tim pelaksana. 2) Pelatihan/Pembekalan awal. Kegiatan ini memberikan materi tentang kewirausahaan, Teknologi Informasi, Kepemimpinan, dan Strategi Pemasaran. 3) Bimbingan teknis. Para peserta dibagi ke dalam 4 kluster yaitu kluster kuliner makanan, snack, minuman, dan kluster kerajinan. Tiap kluster diberikan bimbingan teknis untuk menghasilkan produk. 4) Pendampingan. Pada saat mahasiswa mempraktekkan membuat produk, kegiatan pendampingan dilakukan oleh tim pelaksana dan narasumber yang memberikan bimbingan teknis.

Kegiatan masing-masing kluster dilaksanakan di lokasi UKM karena masih dalam pandemi covid-19 para peserta harus menaati protokol kesehatan. Berbeda dengan dua tahun sebelumnya, bimbingan teknis dan pendampingan dilaksanakan di kampus Fakultas Ekonomi. Saat ini para peserta Program
Pengembangan Kewirausahaan (PPK) mendatangi UKM yang menjadi narasumber atau pelatih. Waktu pelaksanaan kegiatan selama lima bulan.

\section{HASIL DAN PEMBAHASAN}

\section{Peningkatan Kompetensi Kewirausahaan}

Program pengembangan kewirausahaan merupakan kegiatan intervensi kepada mahasiswa sebagai peserta. Kegiatan ini memberikan dampak positif terhadap peserta yaitu berupa ketrampilan kewirausahaan peserta ada peningkatan. Mulai dari proses produksi sampai pada pemasaran. Setelah dilatih dan dibimbing maka terlihat ada peningkatan jiwa wirausaha mereka dibandingkan sebelum mengikuti program ini.

Kegiatan yang dilakukan untuk meningkatkan ketrampilan kewirausahaan adalah sebagai berikut: 1) Pembekalan awal yaitu memberikan materi secara praktis tentang kewirausahaan, kepemimpinan, rencana bisnis, teknologi informasi, dan strategi pemasaran. 2) Bimbingan teknis sesuai dengan kluster yang sudah dipilih oleh mahasiswa yaitu kluster makanan, makanan ringan, minuman, dan kerajinan. 3) Praktek mandiri yaitu para mahasiswa memproduksi sendiri produk sesuai kluster mereka masing-masing. 4) Kunjungan ke UMKM untuk melihat proses produksi dan pemasaran yang dilakukan. 5) Mengikuti pameran yang dalam lingkungan Universitas Negeri Manado.

Salah satu aspek untuk meningkatkan minat wirausaha mahasiswa yaitu dengan memberikan pendidikan atau pengetahuan dan ketrampilan kewirausahaan (Ahmad Tri Atmaja, 2016; Scuotto Veronica, 2013; Hong Mei, 2020). Martin Obschonka dkk (2017) menyatakan bahwa kewirausahaan merupakan ketrampilan abad 21. Peran karakteristik kepribadian dan kompetensi kewirausahaan yang sesuai dengan usia (kepemimpinan, harga diri, kreativitas, dan motivasi proaktif) berpengaruh pada kewaspadaan kewirausahaan dan niat karir.

Keragaman ketrampilan yang dimiliki oleh seseorang dalam bekerja salah satu ketrampilan adalah kewirausahaan atau kompetensi kewirausahaan (Krieger et.al 2018).

Kompetensi kewirausahaan dapat dilihat dari beberapa aspek seperti yang dikemukakan oleh Mitchelmore (2013) Idea generation, 
Innovation skills, Visioning Envisioning opportunities, Product innovation, Creativity, Willingness to take risks, Scan environments for opportunities, Risk taking. Indikator dalam kompetensi kewirausahaan tersebut dapat dimiliki oleh mahasiswa wirausaha jika mereka terlibat langsung dalam kegiatan kewirausahaan. Jika tidak disengaja untuk menambah kompetensi mereka sendiri pasti tidak akan terbentuk. Oleh sebab itu kegiatan sejenis program pengembangan kewirausahaan sebaiknya dilakukan secara terus menerus baik dalam implementasi mata kuliah atau dalam program khusus.

\section{Lahirnya Wirausaha Baru}

Terdapat tujuh peserta PPK yang berhasil memulai usaha meskipun dalam lingkup relatif kecil. Mereka melakukan usaha di tempat kos masing-masing. Ketujuh mahasiswa tersebut tersebar dalam empat kluster. Ketujuh mahasiswa menjalankan usaha dari tempat kos dan dari rumah karena masih diberlakukan PPKM. Omset mereka bervariasi karena tidak setiap hari mereka memproduksi. Lebih jelasnya dapat dilihat pada tabel dibawah ini. Bidang usaha dari peserta produknya sebagai berikut: makanan kwetiau, burger, minuman milkshake dan aneka minuman boba, kerajinan tenun berupa sarung dan selendang, dan kerajinan gerabah.

Tabel 1 Wirausaha baru dan bidang usaha

\begin{tabular}{llll}
\hline No & Nama & Produk & Omset/bln \\
\hline 1 & $\begin{array}{l}\text { Chandra, } \\
\text { Jonathan, }\end{array}$ & Minuman & 3.000 .000 \\
& Jansen & & \\
2 & Mita & Burger & 2.000 .000 \\
3 & Novrianti & Tenun & 1.500 .000 \\
& \& Klaurina & & \\
4 & $\begin{array}{l}\text { Dewi } \\
\text { Sartika }\end{array}$ & Kwetiau & 2.000 .000 \\
5 & Renaldy & Gerabah & 2.500 .000 \\
6 & Novira & O.L. Shop & 3.000 .000 \\
7 & Tirtawati & O.L Shop & 1.500 .000
\end{tabular}

Lahirnya wirausaha dikalangan mahasiswa harus dipersiapkan dan dibentuk di perguruan tinggi. Peran perguruan tinggi untuk memberikan motivasi dan kemampuan kewirausahaan kepada calon lulusan (Tomy dan Pardede, 2020).
Jumlah peserta PPK sebanyak 20 orang belum seluruhnya termotivasi untuk merintis usaha. Hanya 10 orang yang merintis usaha ada yang berkelompok ada juga yang perorangan. Tim Pelaksana sudah tiga tahun melaksanakan program seperti ini, memang tidak mudah untuk merubah pola pikir mereka. Mereka masih memikirkan bagaimana selesai studi tepat waktu tanpa berpikir apakah nanti setelah mereka lulus tidak akan jadi pengangguran. Hal ini yang menjadi tantangan perguruan tinggi khususnya Fakultas Ekonomi untuk tidak memproduksi lulusan yang menjadi pengangguran terdidik.

\section{KESIMPULAN}

Kegiatan pengabdian kepada masyarakat khususnya Program Pengembangan Kewirausahaan dapat dijadikan model untuk melatih mahasiswa menjadi wirausaha baru mandiri. Implementasi program ini menghasilkan 7 mahasiswa tenant yang telah memulai usaha. Manfaat dari program ini dapat dirasakan oleh mahasiswa tenant dan mereka dapat menjadi pemberi motivasi terhadap mahasiswa yang lain untuk berwirausaha. Diperlukan perubahan pola pikir dari mahasiswa untuk suksesnya implementasi program pengembangan kewirausahaan. Selain itu pihak Universitas harus menyediakan fasilitas dan menciptakan atmosfir wirausaha di setiap unit kerja.

Disarankan kepada pengajar mata kuliah kewirausahaan untuk memberikan intervensi guna menghasilkan mahasiswa wirausaha.

\section{UCAPAN TERIMA KASIH}

Direktur Riset dan Pengabdian Masyarakat yang telah membiayai Program Pengembangan Kewirausahaan (PPK) di Fakultas Ekonomi Universitas Negeri Manado.

\section{REFERENSI}

Atmaja, Ahmad Tri, Margunani, (2016), Pengaruh Pendidikan Kewirausahaan Dan Aktivitas Wirausaha Terhadap Minat Berwirausaha Mahasiswa Universitas Negeri Semarang, Economic Education Analysis Journal, (774-787) 
Hong Mei, Ching-Hung Lee,Yuanyuan Xiang,(2020), Entrepreneurship Education and Students' Entrepreneurial Intention in Higher Education,

Krieger, A., Block, J. \& Stuetzer, M. (2018). Skill variety in entrepreneurship: A literature review and research directions. International Review of Entrepreneurship, 16(1), 29-62.

Mitchelmore Siwan, (2013), Entrepreneurial competencies of women entrepreneurs pursuing business growth, Journal of Small Business and Enterprise Development Vol. 20 No. 1, 2013 pp. 125-142

Obschonka, M., Hakkarainen, K., Lonka, K. et al.(2017) Entrepreneurship as a twenty-first century skill: entrepreneurial alertness and intention in the transition to adulthood. Small Bus Econ 48, (487-501)

Scuotto Veronica, Massimo Morellato (2013), Entrepreneurial Knowledge and Digital Competence: Keys for a Success of Student Entrepreneurship

Soputan, G.J, Nova Mamuaya, Made Krisnanda, (2021), Strategi Membentuk Wirausaha baru di Kampus, Jurnal Kewirausahaan dan Bisnis Vol.26 No.1 June 2021,(45-54)

Tomy Sarath and Eric Pardede, (2020), An Entrepreneurial Intention Model Focussing on Higher Education, International Journal of Entrepreneurial Behavior \& Research 


\section{LAMPIRAN}

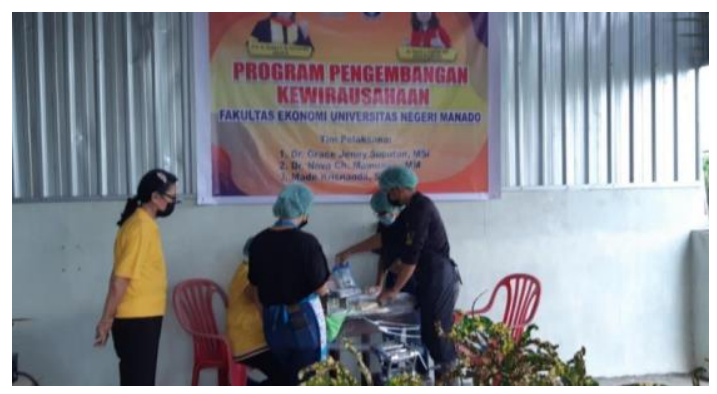

Gambar 1. Bimtek pembuatan Snack ikan tuna

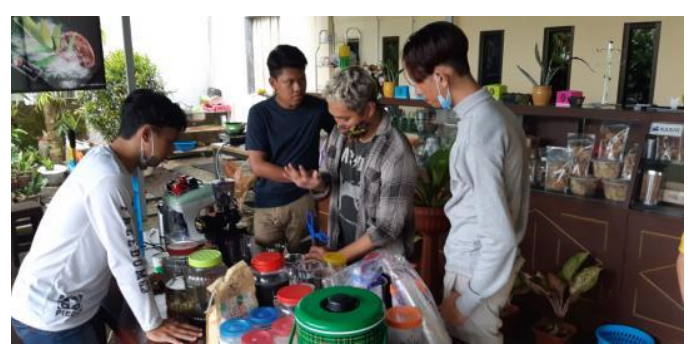

Gambar 2. Bimtek aneka minuman kekinian

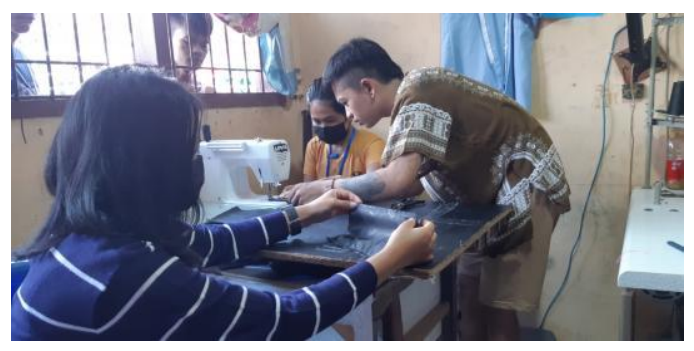

Gambar 3. Bimtek Kerajinan

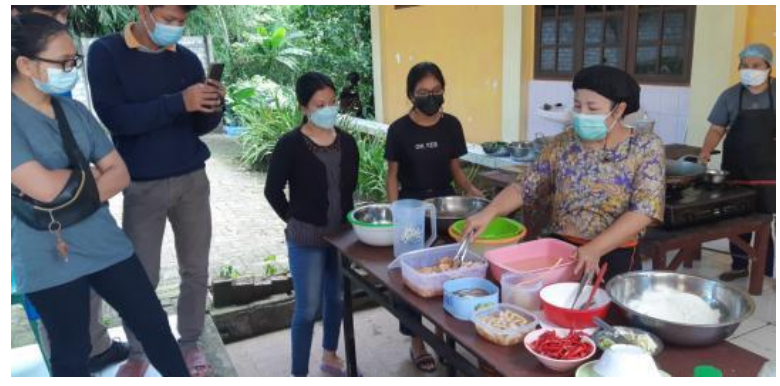

Gambar 4. Bimtek pembuatan aneka makanan Crispy 